UTOPIA, CARNIVAL, AND COMMONWEALTH IN RENAISSANCE ENGLAND 
This page intentionally left blank 


\section{CHRISTOPHER KENDRICK}

\section{Utopia, Carnival, and Commonwealth in}

Renaissance England 


\section{www.utppublishing.com}

(C) University of Toronto Press Incorporated 2004

Toronto Buffalo London

Printed in Canada

ISBN 0-8020-8936-4

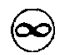

Printed on acid-free paper

\section{National Library of Canada Cataloguing in Publication}

Kendrick, Christopher, 1953-

Utopia, carnival and commonwealth in Renaissance

England / Christopher Kendrick.

Includes bibliographical references and index.

ISBN 0-8020-8936-4

1. English literature - Early modern, 1500-1700 - History and criticism. 2. Utopias in literature. I. Title.

PR418.U8K45 $2004 \quad 820.9^{\prime} 372 \quad$ C2004-901668-7

University of Toronto Press acknowledges the financial assistance to its publishing program of the Canada Council for the Arts and the Ontario Arts Council.

University of Toronto Press acknowledges the financial support for its publishing activities of the Government of Canada through the Book Publishing Industry Development Program (BPIDP). 